\title{
HUBUNGAN STIGMA SOSIAL DAN KUALITAS HIDUP PADA ANAK DENGAN HIV/AIDS DI YAYASAN VSE JAKARTA BARAT
}

\section{The Relationship of Social Stigma and Quality Of Life in Children with HIV/AIDS at The VSE Jakarta Barat Foundation}

\author{
Siti Latipah ${ }^{1}$, Cabela Milanda ${ }^{2}$ \\ ${ }^{1}$ Fakultas Ilmu Kesehatan Universitas Muhammadiyah Tangerang, Indonesia \\ ${ }^{2}$ Fakultas Ilmu Kesehatan Universitas Muhammadiyah Tangerang, Indonesia
}

Korespondensi: Siti Latipah dan sitilatipah142@gmail.com

\begin{abstract}
ABSTRAK
Latar Belakang: HIV (Human Immunodeficiency Virus) adalah sebuah virus yang menyerang sistem kekebalan tubuh manusia. Terdapat banyak faktor yang mempengaruhi memperburuk kualitas hidup pada anak dengan HIV/AIDS seperti stigma sosial yang muncul dilingkungan masyarakat. Stigma sosial yang beredar pada masyarat dan memandang atau diskriminasi anak dengan HIV/AIDS dapat menurunkan kualitas hidup pada anak sehingga tidak mau mengikuti pengobatan atau hilang semangat pada anak dengan HIV/AIDS. Tujuan Penelitian: Mengetahui hubungan stigma sosial dan kualitas hidup pada anak dengan HIV/AIDS. Metedologi: Penelitian ini mengunakan penelitian kuantitatif dengan desain cross sectional, pengumpulan data menggunakan lembar kuesioner stigma sosial dan lembar kuesioner kualitas hidup yang telah di uji validitas dan reliabilitas. Sampel penelitian berjumlah 30 responden yang diambil dengan teknik total sampling. Teknik analisis yang digunakan pada penelitian ini adalah Chi Square. Hasil: Terdapat kualitas hidup tidak baik sebanyak 12 responden $(66,7 \%)$, dan sebanyak 6 responden dengan kualitas hidup baik (33,3\%). Stigma baik sebanyak 12 responden dengan kualitas hidup baik sebanyak $1(8,3 \%)$ dan sebanyak 11 responden memiliki kualitas hidup baik sebesar (91,7\%). Hasil uji stastistik Chi Square menunjukan terdapat hubungan antara stigma sosial dan kualitas hidup dengan $p$-value $=0,02$ dengan nilai normal $<\alpha(0,05)$. Kesimpulan: Hal ini menunjukan stigma sosial berpengaruh pada kualitas hidup anak karenadengan stigma yang ditrima dapat menurun kan imun tubuh anak dan menurunkan kualitas hidup sehari-hari pada anak dengan HIV/AIDS.
\end{abstract}

Kata Kunci: Stigma Sosial; Kualitas Hidup; HIV/AIDS.

\section{ABSTRACT}

Background: HIV (Human Immunodeficiency Virus) is a virus that attacks the human immune system. There are many factors that affect the worsening quality of life in children with HIVIAIDS such as social stigma that appears in the community. The social stigma that circulates in the community and views or decriminalizes children with HIV/AIDS can reduce the quality of life in children so they do not want to take treatment or lose enthusiasm in children with HIV/AIDS. Research Objectives: Knowing the Relationship of Social Stigma and Quality of Life in Children with HIV/AIDS. Methodology: This study uses a quantitative study with a cross sectional design. Data collection uses a social 
stigma questionnaire sheet and a quality of life questionnaire sheet that have been tested for validity and reliability. The research sample amounted to 30 respondents who were taken by total sampling technique. The analytical technique used in this study is Chi Square. Result: There are 12 respondents $(66.7 \%)$, and 6 respondents with good quality of life (33.3\%). There are 12 good stigmatized respondents with good quality of life as much as 1 (8.3\%) and as many as 11 respondents have good quality of life (91.7\%). The results of the Chi Square statistical test show that there is a relationship between social stigma and quality of life with $p$-value $=0.02$ with a normal value $<\alpha$ (0.05). Conclusions: This shows that social stigma affects the quality of life of children because the stigma received can reduce the child's immune system and reduce the quality of daily life in children with HIV/AIDS.

Keywords: Social Stigma; Quality of Life; HIV/AIDS.

\section{PENDAHULUAN}

Human Immunodeficiency

Virus (HIV) merupakan penyakit kronis yang disebabkan oleh retrovirus, HIV pada anak dapat ditularkan secara vertikal, seksual, kontaminasi darah atau penyalahgunaan obat intra vena. Infeksi vertikal HIV bisa terjadi sebelum lahir, persalinan dan setelah lahir. Epidemik tersebut terus merebak ke negara lain dengan puncak yang dikenal pasti bukan hanya dalam golongan homoseksual. Virus ini turut merebak melalui perkongsian jarum suntikan yang tercemar dengan HIV dan ibu yang telah dijangkiti HIV semasa hamil, melahirkan anak dan semasa penyusuan (Andrew, 2005).

Menurut World Health

Organization Quality of Life (WHOQOL) kualitas hidup adalah persepsi individu mengenai posisi individu dalam hidup sesuai konteks budaya dan sistem nilai yang dianutnya, dimana individu hidup dan hubungannya dengan harapan, tujuan, standar yang ditetapkan dan perhatian dari individu. Masalah yang mencakup kualitas hidup sangat luas dan kompleks termasuk masalah kesehatan fisik, status psikologis, tingkat kebebasan, hubungan sosial, dan lingkungan dimana mereka berada.

Menurut Goffman (1963) stigma mengacu pada tanda tubuh yanng dirancang untuk mengekspos sesuatu yang tidak biasa dan buruk tentang status moral individu. Tandatanda tersebut terpampang dan terpasang ke dalam tubuh dan menekankan bahwa individu tersebut adalah seorang budak, penjahat, penghianat atau orang yang tercemar, dimana secara ritual orang yang tercemar harus dihindari terutama di tempat umum.

Meskipun cenderung fluktuatif, data kasus HIV di Indonesia terus meningkat dari tahun ke tahun. Data yang didapatkan dari infodatin HIV AIDS, terlihat bahwa selama sebelas tahun terakhir jumlah kasus HIV di Indonesia mencapai puncaknya pada tahun 2019, yaitu sebanyak 50.282 kasus. Berdasarkan data WHO tahun 2019, terdapat 78\% infeksi HIV baru di regional Asia Pasifik. Untuk kasus HIV tertinggi selama sebelas tahun terakhir pada tahun 2013, yaitu 12.214 kasus (SIHA, 2019).

Berdasarka data meningkatkanya kasus HIV/AIDS 
pada anak di Indonesia, stigma yang dihadapi oleh anak juga mempengarui pertumbungan dan perkembagam serta kelanjutan proses daur kehidupan begitu kompleks yang dihadapi. Peneliti tertarik dengan tema "hubungan stigma sosial dan kualitas hidup pada anak dengan HIV/AIDS di Yayasan Vina Smart Era (VSE) Jakarta".

\section{TUJUAN PENELITIAN}

Tujuan penelitian ini adalah untuk mengetahui hubungan antara stigma sosial dengan kualitas hidup pada anak dengan HIV/AIDS di Yayasan VSE Jakarta.

\section{METODE PENELITIAN}

Penelitian ini merupakan penelitian kuantitatif dengan desain penelitian deskritif kolerasional dengan pendekatan cross sectional untuk mengetahui apakah terdapat hubungan antara stigma sosial dan kualitas hidup pada anak dengan hiv aids. Populasi dalam penelitian ini yaitu anak dengan HIV/AIDS di (VSE) berjumlah 30 responden.

Kriteria inklusi pada penelitian ini, yaitu:

1) Anak dengan penderita HIV/AIDS

2) Anak yang sudah mampu baca dan tulis

3) Anak bersedia menjadi responden

4) Anak yang tidak mengalami sakit berat.

Teknik pengambilan sampel pada penelitian ini menggunakan teknik total sampling. Penelitian ini menggunakan alat ukur kuesioner dari penelitian sebelumnya. Kuesioner yang digunakan pada penelitian ini berjumlah 2, sebagai berikut: instumen kuesioner A tentang stigma sosial terdiri dari 2 subtema yaitu personalisasi dan sikap masyarakat dengan menggunakan 26 pertanyaan, instrumen kuesioner B tentang kualitas hidup menggunakan instrumen baku pediatric Quality of Live Inventary (PedsQL) dengan menggunkan 16 item pertanyaan terdiri dari kesehatan dan aktivitas, perasaan, pergaulan. Peneliti melakukan uji validitas dan reliabilitas, uji validitas menggunakan jenis uji validitas dan uji reliabilitas menggunakan jenis metode cronbach alpha. Analisis bivariat dilakukan untuk menggunakan ada tidaknya hubungan yang bermakna secara statistik antar variabel dependen dan independen dengan Uji Chi-Square dengan program komputerisasi.

\section{HASIL PENELITIAN}

Tabel 1. Karakteristik Usia Anak dengan HIV/AIDS

\begin{tabular}{ccc}
\hline Usia & Frekuensi & Presentase $(\%)$ \\
\hline 14 th & 4 & 13,3 \\
\hline 15 th & 7 & 23,3 \\
\hline 16 th & 10 & 33,3 \\
\hline 17 th & 5 & 16,7 \\
\hline 18 th & 4 & 13,3 \\
\hline Total & 30 & 100 \\
\hline
\end{tabular}

Berdasarkan dari tabel di atas menunjukan hasil bahwa golongan usia anak dengan HIV/AIDS di Yayasan VSE, dari total 30 responden terdapat 10 responden $(33,3 \%)$ berusia 16 tahun dimana usia terbanyak dalam kategori usia remaja.

Tabel 2. Stigma Sosial pada Anak dengan HIV/AIDS

\begin{tabular}{ccc}
\hline Stigma Sosial & Frekuensi & $\begin{array}{c}\text { Presentase } \\
(\%)\end{array}$ \\
\hline Stigma Sosial & 23 & $76,7 \%$ \\
\hline
\end{tabular}


Siti Latipah \& Cabela Milanda: Hubungan Stigma Sosial dan Kualitas Hidup pada Anak Dengan HIV/AIDS di Yayasan VSE Jakarta Barat

\begin{tabular}{ccc}
\hline Kurang Baik & & \\
\hline Stigma Sosial Baik & 7 & $23,3 \%$ \\
\hline Total & 30 & $100 \%$ \\
\hline
\end{tabular}

Berdasarkan keterangan dari tabel menunjukan hasil krakteristik stigma sosial dari 30 responden terdapat 23 responden $(76,7 \%)$ dengan stigma sosial kurang baik.

Tabel 3. Kualitas Hidup pada Anak dengan HIV/AIDS

\begin{tabular}{ccc}
\hline $\begin{array}{c}\text { Kualtitas } \\
\text { Hidup }\end{array}$ & Frekuensi & $\begin{array}{c}\text { Presentase } \\
(\%)\end{array}$ \\
\hline $\begin{array}{c}\text { Kualitas } \\
\text { Hidup Tidak } \\
\text { Baik }\end{array}$ & 24 & $62 \%$ \\
\hline $\begin{array}{c}\text { Kualitas } \\
\text { Hidup Baik }\end{array}$ & 6 & $38 \%$ \\
\hline Total & 30 & $100 \%$ \\
\hline
\end{tabular}

Berdasarkan keterangan dari tabel menunjukan hasil krakteristik kualitas hidup dari 30 responden terdapat 24 responden (62\%) dengan kualitas hidup tidak baik.

Tabel 4. Hubungan Stigma Sosial dengan Kualitas Hidup pada Anak dengan HIV/AIDS

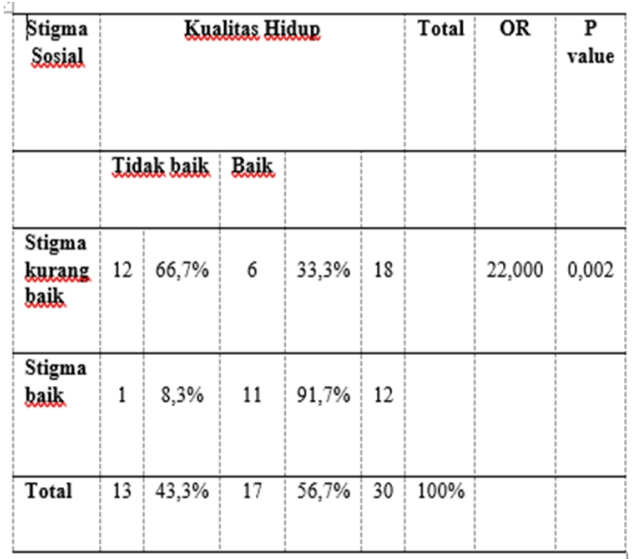

Berdasarkan keterangan dari tabel hasil penelitian diperoleh dari 30 responden. Responden dengan stigma kurang baik sebanyak 18 responden dengan kualitas hidup tidak baik sebanyak $12(66,7 \%)$, dan sebanyak 6 responden dengan kualitas hidup baik (33,3\%). Sedangkan responden dengan stigma baik sebanyak 12 responden dengan kualitas hidup baik sebanyak $1(8,3 \%)$ dan sebanyak 11 responden memiliki kualitas hidup baik sebesar $(91,7 \%)$. Jadi stigma sosial yang kurang baik berpengaruh pada kualitas hidup responden dengan hasil OR 22,000 yang mempengaruhi stigma sosial dan kualitas hidup pada responden.

Hasil uji statistik yang diperoleh dengan menggunakan rumus Chi Square dengan tabel distribusi $2 \times 2$ menunjukan bahwa hasil nilai pvalue 0,002 artinya nilai pvalue $<0,05$, maka penelitian ini disimpulkan ada hubungan stigma sosial dengan kualitas hidup pada anak dengan HIV/AIDS di Yayasan VSE.

\section{PEMBAHASAN \\ Karakteristik usia anak dengan HIV/AIDS}

Rasio jumlah kasus laki-laki dan perempuan adalah 3 berbanding 1, meskipun jumlah perempuan penderita HIV/AIDS lebih sedikit, dampak pada perempuan lebih besar, baik dalam masalah kesehatan maupun sosial ekonomi. Perempuan lebih rentan tertular dan lebih menderita akibat infeksi ini. Penularan pada perempuan akan berlanjut dengan penularan pada bayi di masa kehamilan. Risiko penularannya berkisar 15-40\%. Selain itu bayi yang lahir dari seorang ibu dengan HIV/AIDS mungkin akan terinfeksi HIV/AIDS sebelum, selama, atau sesudah proses kelahirannya. Penularan juga dapat terjadi melalui Air Susu Ibu (ASI). 
Anak tersebut akan tumbuh dan berkembang dengan HIV/AIDS di dalam tubuhnya. Di Indonesia, hingga tahun 2020, pengidap HIV/AIDS pada anak dan remaja usia dibawah 19 tahun terus meningkat, mencapai 3.881 orang.

Meningkatnya jumlah kasus pada anak menimbulkan fenomena dan permaslahan baru. Masalah yang dihadapai oleh anak dan remaja dilihat dari aspek pertumbuhan dan perkembangan antara lain:

1. Fisik

Anak yang mengidap HIV/AIDS akan mengalami gangguan kesehatan antara lain: gangguan pertumbuhan dan perkembangan, gizi kurang, sering sakit. Anak yang sedang dalam pemberian pengobatan ARV akan mengalami gejala efek samping obat, antar lain: perut kembung dan terkadang mual. Hal ini akan mempengaruhi aktivitas kesehariaan anak, pada akhirnya menjadi kurang energik, bertenaga, sehingga menghambat kegiatan keseharian anak.

\section{Psikologis}

Anak dengan HIV/AIDS dikarenakan sering sakit dan mengkonsusi obat secara terus menurus dan seumur hidup akan menimbulkan gangguan dari efek obat tersebut, dan masalah psikologis karena hubungan pertemanan dan penerimaan dari lingkungan luar. Stigma dan diskriminasi serta labeling yang melekat pada anak tersebut akan menjadikan perubahan perilaku pada anak. Jika koping kurang baik (desktruktif) maka anak akan mengalami gangguan psikolgis seperti: stress, depresi.

\section{Pendidikan}

Anak dengan HIV/AIDS dalam masa sekolah akan terhambat yang pertama karena kondisi lemah, sering absen sehingga penerimaan pengetahuan atau prestasi menurun, selanjutnya dampak pegobatan akan mengalami sering absen dan stigma dari pihak sekolah yang sering dijauhi oleh teman bahkan dari pihak guru, anak dengan HIV/AIDS terkadang dijauhi bahkan duduk di kelas dipisahkan oleh gurunya, dikhawatirkan menular ke temanya. Kasus lebih ekstrim lagi ada pihak sekolah yang menolak anak dengan HIV/AIDS, hal ini akan berdampak pada aspek psikologis

4. Sosial

Anak dengan HIV/AIDS akan mengalami hambatan dalam aspek sosial karena sering di jauhi dan ditakuti oleh teman sebaya. Teman sebaya memberikan labeling bahwa dia adalah anak dari orang tua pendosa, kotor, penyakit kutukan.

\section{Stigma}

Stigma dari keluarga akan muncul jika mengetahui ada salah satu kerabatnya yang mengidap HIV/AIDS, jangankan untuk berjabat tangan, memeluk, bahkan untuk melewati rumahnya saja mereka khawatir dengan alasan akan tertular HIV/AIDS. Stigma sosial karena pandangan bahwa HIV/AIDS adalah penyakit yang menular, mematikan, dan penyakit kutukan, perlahan namun pasti menghindar untuk sekedar bertemu, atau bahkan berkumpul untuk melakukan tugas bersama atau main bersama.

\section{Stigma sosial pada anak dengan HIV/AIDS}

Hasil penelitian ini terkait dengan aspek stigma sosial kurang 
baik sebanyak $13(43,3 \%)$ dari 30 responden yang diteliti. Hal ini sejalan dengan penelitian Sugiharti, et al (2019) menunjukan bahwa stigma sosial yang kurang baik mengarah negatif terhadap anak dengan HIV. Stigma sosial mengacu pada tanda tubuh yanng dirancang untuk mengekspos sesuatu yang tidak biasa dan buruk tentang status moral individu sesuai dengan pendapat Goffman (1964).

Stigma yang mempengaruhi dari sikap masyarakat pada penelitian ini dilihat dari cara padangan masyarkat bahwa HIV/AIDS adalah penyakit kutukan, penyakit sangat menular, penyakit yang ditimbulkan oleh perilaku buruk, penyakit yang tidak ada obatnya dan mematikan.

Masyarakat khususnya ibuibu yang memiliki anak sebaya dengan anak dengan HIV/AIDS ini tentunya akan melarang anaknya untuk bergaul atau bermain, belajar bersama.

Dari pihak sekolah saat mengetahui anak tersebut mengidap HIV/AIDS, akan dijauhi dan terkadang tempat duduknya sendiri terpisah dengan murid lain, bahkan ada yang merekomendasikan untuk pindah sekolah.

Dari pihak pelayanan kesehatan, saat ini pengambilan obat ARV telah tersedia secara gratis di RS dan Puskesmas, namun untuk memfasilitasi ruang tunggu saat pengambilan obat belum telihat memihak kepada golongan anakanak, ini terbukti belum tersedianya playgroud atau tempat bermain di ruang tunggu saat berobat.

Kesimpulan pada hasil penelitian stigma sosial sikap masyarakat atau pandangan dari masyarakat dapat mempengaruhi terapi atau pengobatan pada anak dengan HIV/AIDS.

\section{Kualitas hidup pada anak dengan HIV/AIDS}

Hasil penelitian ini
menunjukan bahwa dari total responden 30 responden yang telah diteliti ada sebanyak 13 responden dengan total presentasenya $(43,3 \%)$ memiliki kualitas hidup yang kurang baik. Hal ini sejalan dengan penelitian Muhaimin (2019). Kualitas hidup adalah persepsi individu mengenai posisi individu dalam hidup sesuai konteks budaya dan sistem nilai yang dianutnya, dimana individu hidup dan hubungannya dengan harapan, tujuan, standar yang ditetapkan dan perhatian dari individu sesuai dengan pendapat WHO (2019).

Anak dengan HIV/AIDS memiliki kualitas hidup kurang baik, disebabkan oleh banyak faktor. Pertama karena proses biologi hiv tersebut yang mempengaruhi fisiknya. Kedua karena proses intervensi atau pengobat karena ARV tetap memiliki efek sampin. Ketiga karena faktor stigma baik yang diterima dari stigma diri sendiri, stigma keluarga, stigma sosial dan stigma dari pelayanan kesehatan. Hal tersebut memberikan pengaruh terhadap kuaitas hidup anak tersebut.

\section{Hubungan stigma sosial dengan kualitas hidup pada anak dengan HIV/AIDS}

Hasil penelitian menunjukan bahwa hasil penelitian diperoleh dari 30 responden. Responden dengan stigma kurang baik sebanyak 18 responden dengan kualitas hidup tidak baik sebanyak $12(66,7 \%)$, dan sebanyak 6 responden dengan kualitas hidup baik (33,3\%). 
Sedangkan responden dengan stigma baik sebanyak 12 responden dengan kualitas hidup baik sebanyak $1(8,3 \%)$ dan sebanyak 11 responden memiliki kualitas hidup baik sebesar $(91,7 \%)$. Hasil uji stastistic ChiSquare di peroleh $\mathrm{OR}=22,000$ dengan tabel distribusi kontigenasi 2x2. Dimana nilai Pvalue $=0,002$ (pvalue $<0,05)$ maka Ho ditolak yang artinya adanya hubungan antara sitigma sosial dan kualitas hidup pada anak dengan HIV di Yayasan VSE. Hasil penelitian ini sesuai dengan hasil penelitian Lise-Lott Rydström (2018). Stigma yang menjadi tolak ukur msyarakat terhadap orang dengan HIV menjadi dan mempengaruhi penurunan kualitas pada anak. Penelitian tersebut adanya hubungan stigma sosial dan kualitas hidup anak dengan HIV/AIDS dapat mempengarui penurunan kesehatan pada anak.

Stigma yang di terima akan memperburuk kondisi anak dengan HIV/AIDS. Stigma social yang diterim dari luar antra lain: penolakan dari lingkungan rumah, setelah orang tua teman sebaya mengetahui kondisi anak dnegan HIV/AIDS mereka akan melarang anak mereka untuk bermain dnegan anak penderita HIV/AIDS. Selain di lingkungan rumah, lingkungan kekerabatan yang mulai menjauh, biasanya anak akan mencium tangan sanak saudara, berpelukan saat berkunjung atau bertemu dalam kesempatan pertemuan keluarga hal ini tidak dilakukan, jangankan memeluk, untuk berjabat tangan dan makan bersama saja mereka menghindar. Stigma sosial yang di dapat ini tentunya akan merubah perilaku dan berdampak pada psikologis dan ini akan mempengarhi kualitas hidup bagi anak dengan HIV/AIDS.

Penanganan HIV/AIDS tidak hanya mengandalkan intervensi ARV namun harus bersifat holsitik, untuk melengkapi pengobatan semua unsur dilibatkan, aspek gizi, complementary, spritualitas, psikososial. Salah satu unsur adalah menghilangkan stigma sosial sehingga akan meningkatkan kualitas hidupa nak dnegan HIV/AIDS.

\section{KESIMPULAN}

Masalah yang berkembang di masyarakat adalah individu yang mengidap HIV/AIDS mendapatkan tekanan bukan saja akibat pengaruh intervensi atau pengobatan hiv di dalam tubuhnya, tetapi juga penderita dihadapkan pada stigma dan diskriminasi. Dengan adanya program Highly Active Antiretroviral Therapy (HAART), mestinya angka kesakitan karena HIV/AIDS menurun, namun kenyataanya angka kesakitan dan kematian msaih tetap tinggi.

Faktor penting untuk mendapatkan perhatian serius adalah perlunya pendekatan secara holistic, dengan melakukan intervensi dari berbagai lini tidak hanya mengandalkan pendekatan terapi antoretrovital (ARV) saja namun perlu meningkatkan aspek gizi, complentary, aspek spiritualitas dan peran dukungan psikososial.

Dukungan psikosial mempunya arti penting untuk meningkatkan kualitas hidup dan memperpanjang umur harapan hidup penderita HIV/AIDS. Kondisi ini dipengaruhi oleh proses penerimaan diri (acceptance), selain itu perlu menciptakan homestastis pada penderita HIV/AIDS memalui pemberian ARV serta dukungan 
psikososial. Terapi ARV bermanfaat meredam efek biologi HIV, dukungan psikososial akan meminimalkan tekanan psikologi serta psikososial penderita.

\section{DAFTAR PUSTAKA}

Alfianto, S. (2013). Dinamika Perkembangan Pemanfaatan Teknologi Informasi dan Komunikasi Serta Implikasinya di Masyarakat. Jakarta: Media Bangsa.

Ardhiyanti, Y., Lusiana, N., \& Megasari, K. (2015). Bahan Ajar AIDS Pada Asuhan Kebidanan. Yogyakarta: CV Budi Utama.

BBC News Indonesia. (2019, Februari 12). Dipetik Februari 2019, 18, dari BBC News Indonesia: https://www.bbc.com/indones ia/amp

Becquet R, Marston M, Dabis F, Moulton LH, Gray G, Coovadia HM, \& Essex M. (2012). Children Who Acquire HIV Infection Perinatally Are at Higher Risk of Early Death than Those Acquiring Infection through Breastmilk. PLos ONE, 1-8.

Cahyati, W. H., \& Ningrum, D. N. (2013). Biostatistika Inferensial. Semarang: Jurusan Ilmu Kesehatan Masyarakat.

Chai, G., Kazuhiko, M., Xiaonan, W., \& Khonglai, Z. (2007). Knowledge, Attitudes, Beliefs, and Practices of Chinese Migrants in Nairobi, Kenya and Dar Es Salaam, Tanzania toward HIV/AIDS. Tropical Medicine and Health, 11-18.
Dinkes. (2017). Profil Kesehatan Provinsi Jawa Tengah Tahun 2017. Semarang: Dinas Kesehatan Provinsi Jawa Tengah.

Ditjen P2P. (2017). Laporan Situasi Perkembangan HIV IDS \& PIMS di Indonesia Bulan Januari sampai Desember 2017. Jakarta: Kementerian Kesehatan.

Eunike, R. R. (2005). Psikologi Kesehatan . Semarang: Universitas Negeri Semarang Press.

Febrianti. (2017, June). FaktorFaktor yang Berhubungan dengan Stigma terhadap Orang Dengan HIV dan AIDS (ODHA). Journal Endurance, 2, 158-167.

Fitriani, E. (2018, Mei 17). Solo Tribunnews. Diambil kembali dari Tribun Solo: solo.tribunnews.com

Hati, K., Shaluhiyah, Z., \& Suryoputro, A. (2017, Januari). Stigma Masyarakat terhadap ODHA di Kota Kupangn Provnsi NTT. Jurnal Promosi Promosi Kesehatan Indonesia, 12, 6277.

Herek, G., Capitanio, J., \& Widaman, K. (2002). HIV related stigma and knowledge in the United States: prevalence and trends 1991-1999.

American Journal of Public Health, 371-7.

Hidayat, U. R., Waluyo, A., \& Maria, R. (2017). Sikap Masyarakat pada ODHA didesa Serangkat Kabupaten Bengkayang Propinsi Kalimantan Barat. Jurnal Vokasi Kesehatan, 1, 22-27.

Hossain, M., \& Kippax, S. (2010). 
Stigmatized Attitudes

Toward People Livibf With

HIV in Bangladesh Health

Care Workers' Perspectives.

Asia-Pacific Journal Public

Health, 171-182.

Katili, M. I., Indrati, R., \& Kartikasari, Y. (2012). Sikap dan Tindakan Ibu denganHIV AIDS terhadap Stigma dan Diskriminasi Masyrakart di Kota Semarang. LINK, 8, 215-220.

Kemenkes. (2014). Situasi dan Analisis HIV AIDS. Jakarta: Pusat Data dan Informasi.

Kemenkes. (2017). Profil Kesehatan Indonesia Tahun 2017. Jakarta: Kementerian Kesehatan Republik Indonesia.

Komisi Penanggulangan AIDS Jawa Tengah. (2010). Peraturan Gubernur Nomor 72 Tahun 2010. Semarang: Komisi Penanggulangan AIDS Jawa Tengah.

Li, X., Wang, H., He, G., Fennie, K., \& Williams, A. (2012). Shadow on my heart: a culturally grounded concept of HIV stigma among Chinese injection drug users. Journal of the Association of Nurses in AIDS Care, 52-6. 